\title{
How to Teach Global Challenges? A Solution-Focused Approach
}

Thomas Hoffmann, Teacher Training Centre, Karlsruhe, Germany

\begin{abstract}
Our present and our future are determined by massive global challenges. While the United Nations' Agenda 2030 attempts a global answer to cope with these challenges, schooling in general and Geography teaching in particular, have to find answers for how to deal with challenges such as climate change, loss of biodiversity, water scarcity, poverty or migration. Historically, a mainly problem-oriented teaching approach shaped the learning settings on these topics, with most of the lesson time dedicated to the problem. A solution-focused teaching approach, presented here, makes the solution the main focus in terms of time, thoughts, creativity and discussion, without neglecting the challenges. This approach considers principles of Education for Sustainable Development and contributes extensively to the key competences it strives for. By means of concrete examples from Germany and India and suitable elements such as 'stories of change', this paper explains and reflects on this innovative teaching approach.
\end{abstract}

Keywords: global challenges, Geography teaching, solution-oriented teaching, Education for Sustainable Development

Editor's note: This is the English version of a German article, which has been published in a volume of Hannover University as:

Hoffmann, T. (2022). Globale Herausforderungen und SDGs - ein strikt lösungsorientierter Unterrichtsansatz. In A. Eberth, \& C. Meyer (Hrsg.), SDG Education - Die Sustainable Development Goals mit digitalen Medien erschließen und reflektieren (33-41). Hannover: Institut für Didaktik der Naturwissenschaften, Leibniz Universität.

Online: $\underline{\text { https://doi.org/10.15488/11669 }}$ 
The Earth rising above the lunar horizon, photographed by the astronauts of the Apollo mission in 1968, introduced billions of people for the first time to the immense beauty of the Earth, but above all, to its vulnerability. Protected by a remarkably thin atmosphere, the Earth and its ever-increasing population moves through infinite space. More than half a century has passed since this eye-opening vision without this awareness being adequately reflected in our actions. Rather, we as a global society are acting less and less sustainably, as reflected, for example, in the annual scheduling of Earth Overshoot Day. In the 1970s we only overstretched the Earth's regenerative capacity by a few days in December; in 2019 this was 1 August. By that time, we had used up the planet's regenerative resources for the entire year, and from then on we have been living on what has been an ever-dwindling store.

This general overexploitation of the planetary system is accompanied by a multitude of global challenges, to which the United Nations has most recently responded with the Agenda 2030 and its 17 Sustainable Development Goals (SDGs) (United Nations, 2015; Martens \& Obenland, 2017). Agenda 2030 sets out the targets that each country must achieve on its own, and the world as a whole, by 31 December 2030. Such an undertaking can only be approached as a process involving society as a whole, and consequently the institution of schooling in the broadest sense must also consider what contribution it can make to this agenda, and how the SDGs can best be integrated into teaching.

\section{Working with global challenges and SDGs}

As Jürgen Osterhammel (2016) impressively explained in his work Die Verwandlung der Welt (The Transformation of the World), the decisive course was set in the 19th century for the globalised world in which we live today. We are experiencing the positive consequences of this historic change of course in the form of dramatically improved standards of living for many; the enormous increase in our mobility options; and longer life expectancy by decades due to better nutrition, hygiene, education and health care. On the negative side, we have been experiencing since the middle of the 20th century an exorbitant increase in the demand for resources of all kinds, a dramatic strain on and destruction of the natural environment, and increasing radii of action for more people in shorter periods of time within the framework of a globalised economy (Welzer, 2014, 2019; Hoffmann, 2018a; Göpel, 2020). In the past decade, a team led by Will Steffens not only introduced these developments into the discussion under the title "The Great Acceleration" (see Figure 1), but also made them visible by means of impressive graphics. These have become a symbol of the Anthropocene, i.e. the approach that describes the present as the 'Age of Man' according to the logic by which the most influential factor gives its name to the designation of geological periods (cf. Steffens et al., 2015). 
Socio-economic trends
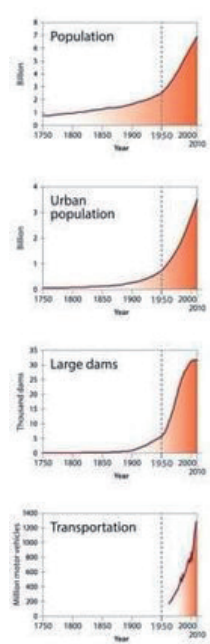

ino 1000 ind
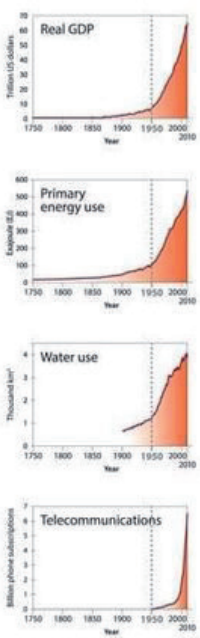

Updated Great Acceleration Graphs
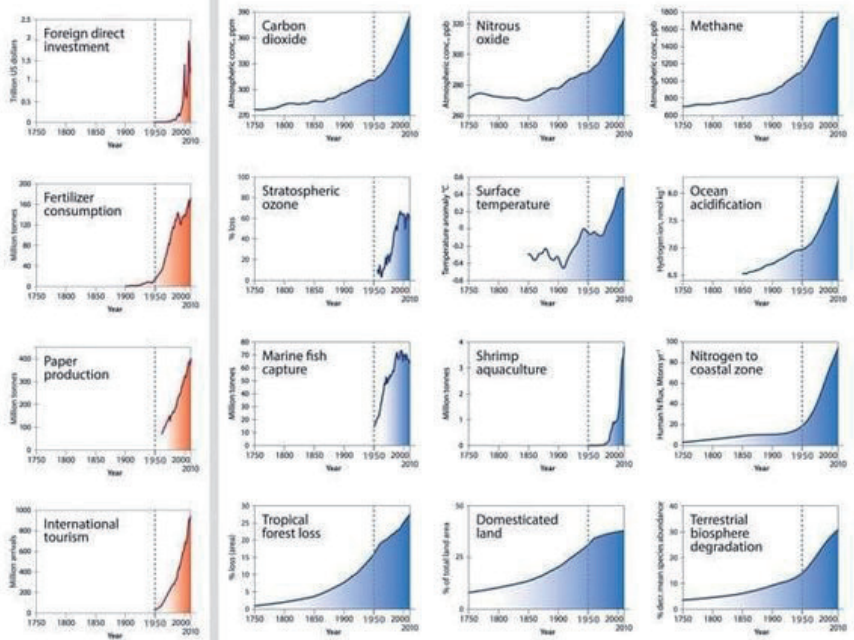

The associated consequences have neither a local nor a regional limitation; they have a global impact. These global challenges, i.e. existential problems that occur simultaneously on at least two continents, determine to a considerable extent the worldwide living realities of the present and the expected near future (Hoffmann, 2018a). This applies to anthropogenic climate change which, according to the current state of affairs, and contrary to all agreements of the Paris Climate Summit of 2015, is expected to reach not $+1.5^{\circ} \mathrm{C}$ to a maximum of $+2^{\circ} \mathrm{C}$ by the end of the century, but an increase in the global average temperature of $+3.6^{\circ} \mathrm{C}$. It applies equally to numerous other global challenges. For example, the World Biodiversity Council (IPBES, 2021) puts the number of species directly threatened with extinction at one million. The global dimension of soil degradation, which is as yet being addressed only very tentatively by global policy makers, is also documented by frightening figures: less than $15 \%$ of global soils that could potentially be used for agricultural production are still available, while at the same time tens of millions of additional hectares of arable soils are lost every year through erosion, contamination, overbuilding and salinisation - a reality that has entered the discussion as "Peak Soil".

In addition to the continued dominance of climate-damaging energy supplies based on fossil fuels and energy-intensive lifestyles, the main causes of these developments are landuse systems that massively affect soils and biodiversity, as the German Advisory Council on Global Change (WBGU) pointed out in its latest report, Rethinking Land in the Anthropocene: From Separation to Integration (WBGU, 2021). Furthermore, massive quantitative as well as qualitative supply problems with drinking water are emerging, particularly in the semi-arid 
regions of the world, as a result of climate change. Global phosphorus and nitrogen cycles are increasingly dysfunctional, and the $\mathrm{pH}$ value of the oceans has already shifted by one decimal from 8.2 to 8.1 (from the slightly basic towards the acidic sphere) over the past two hundred years. The planetary boundaries, as identified by researchers at the Stockholm Resilience Centre over the past decade (see Figure 2), have in the meantime, according to their assessment, already been exceeded with respect to functional biodiversity and phosphorus and nitrogen cycles to an extent that threatens their regenerative capacity, while other areas, such as the freshwater issue, ocean acidification and also climate change, are currently still seen to be within the resilient range of the Earth system. About others, namely the emergence of new substances or atmospheric aerosols, too little is currently known to make a qualified assessment of their state (cf. Steffens, et al., 2015).

Figure 2: Planetary boundaries (Steffens, et al., 2015)

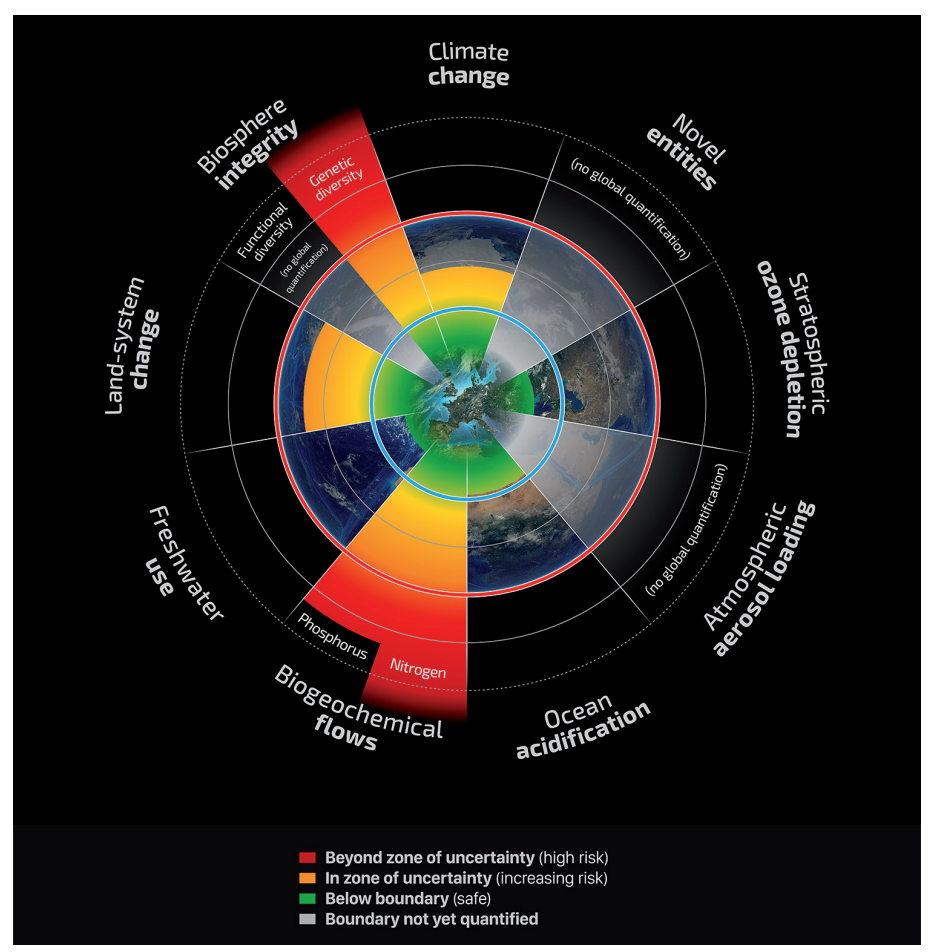

In addition to these natural system stress limits of the Earth system, Kate Raworth and colleagues have summarised and quantified the socio-economic dimensions of global challenges in the 'Doughnut Economics' model (Raworth, 2016; see Figure 3). This illustrates how, in addition to the ecosystem challenges identified and assessed by the Stockholm Resilience Centre, poverty, access to clean drinking water, education, resilience, political voice, labour, energy supply, social equity, gender justice, health and nutrition describe the 
socio-economic challenges of the global society, which are expressed worldwide in the form of hunger, disease, or increasing migration processes.

Figure 3: Doughnut Economics model (Raworth, 2016)

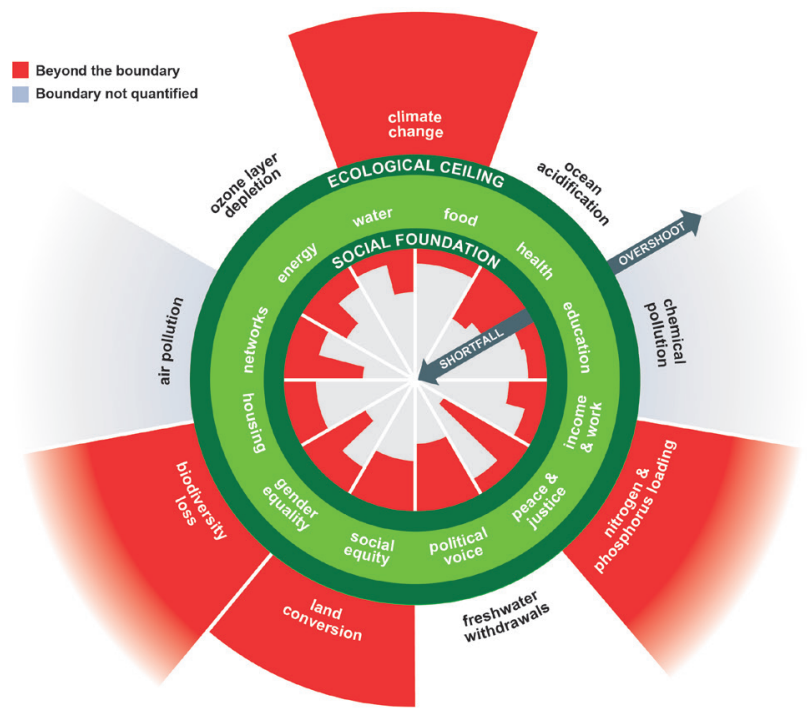

In many cases, these global challenges are not communicated with a systemic understanding, but are perceived, discussed and also taught additively. This does not do justice to their multiple interdependent causal links and consequently makes it difficult to identify meaningful approaches to solutions. However, it is precisely these - causal links and solutions - that should be given special attention in the context of Geography, Science and related subjects.

With the Millennium Development Programme, the world community attempted for the first time at the turn of the millennium to address global challenges in an approach based on the principle of sustainability. However, the limited commitment of the programme to the countries of the Global South and the overly disproportionate emphasis on social aspects in the eight fields of action and their objectives (halving the number of hungry and poor people, primary education for all children, gender equality, reducing child mortality, improving maternal health, combating HIV/AIDS, improving environmental protection and building a global partnership) meant that the frequently voiced structural criticism could not be dismissed out of hand. Nevertheless, during the 15-year period from 2000 to 2015, striking successes were recorded regionally, particularly in Southeast and East Asia, and sectorally, especially with regard to the reduction of maternal mortality and increasing educational access. However, there was no sense of overcoming the global challenges as a whole. 
Thus, it was important to follow up the Millennium Development Programme with another world development programme, Agenda 2030, which was adopted by the United Nations General Assembly on 25 September 2015 and has been in force since 1 January 2016. With a total of 17 goals for sustainable development, the SDGs, the United Nations is ultimately responding to the real global challenges. This overcomes the structural deficits of the Millennium Programme, in that the target formulations are now binding for all countries and, in addition, the sustainability approach has been applied much more broadly.

Figure 4: The Sustainable Development Goals (https://commons.wikimedia.org/wiki/File:Sustainable_ Development_Goals.svg)
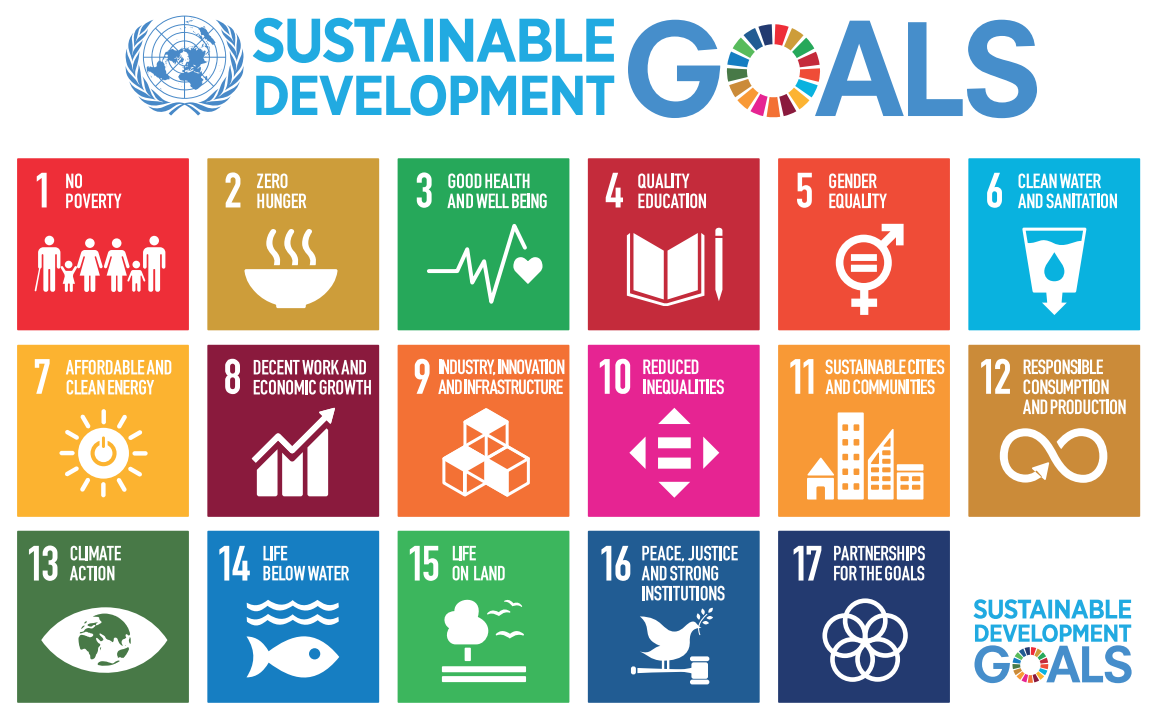

In order to achieve these goals, SDG 4 (Education for Sustainable Development), is of particular importance. On the one hand, the SDGs themselves are a form of learning content; on the other hand, they are a necessary tool for achieving the goals set out in the SDGs as a responsible society. Inevitably, the question arises: how to deal with the SDGs (or their flip side, the global challenges), in the classroom in the most adequate way?

\section{How can global challenges be dealt with in (Geography) lessons?}

Firstly, we need to gain clarity regarding the teaching objective:

- Is it only about the cognitive perception of global challenges and their associated SDGs?

- Should the dimensions, causes and consequences of the global challenges be addressed using a causality-oriented approach? 
- Or should approaches to overcoming global challenges also be the subject of the lessons?

Although both the SDGs and the term 'global challenges' have only been formulated in a few Geography education plans in Germany (for example, in Baden-Württemberg and Lower Saxony), these are fixed components of Geography curricula and education plans of all types of school in all federal states and beyond the borders, ranging from climate change and water crisis to species loss and desertification to soil degradation, poverty, migration and urbanisation. The guidelines laid down in individual curricula on addressing these topics vary widely in terms of their objectives and thus offer varying scope for concrete implementation. To find consensus in view of this diversity, Agenda 2030 can certainly offer guidance (cf. Martens \& Obenland, 2017). At the operational implementation level of the targets of Agenda 2030, the following formulation has been agreed for SDG 4.7:

By 2030, ensure that all learners acquire the knowledge and skills necessary to promote sustainable development, including through education for sustainable development and sustainable lifestyles, human rights, gender equality, a culture of peace and non-violence, global citizenship, and an appreciation of cultural diversity and culture's contribution to sustainable development (United Nations, 2015, p. 19).

Thus, we have a solution- and action-oriented objective focused on individual competence development. The competencies that learners of all ages and from all social contexts should develop concretely in relation to sustainable development determined the discussion that took place for decades at national as well as international levels. With the publication Education for Sustainable Development: Learning objectives issued by UNESCO in 2017, this discussion came to a final consensus in my view. According to this guideline, the development of eight key competencies is to be promoted within the framework of Education for Sustainable Development. These include:

- the competence to think critically,

- systemic competence,

- the competence to anticipate,

- normative competence,

- integrated problem-solving competence,

- strategic competence,

- collaboration competence, as well as

- the competence for self-awareness.

Equipped with these competencies, according to UNESCO's vision, each individual citizen is empowered to make an active contribution to society's overall development towards a sustainable society. This competency approach has since been widely accepted and underlies a number of publications, including Teaching Sustainable Development Goals (Hoffmann \& Gorana, 2017). 
This approach is not fundamentally alien to Social Science, Social Studies or Geography teaching in Germany. In particular, in Social Sciences, a problem-(solution-) oriented approach to the design of lessons has developed over decades. This approach is still widely used in textbooks and teaching materials and is also the basis of many contributions to Geography didactics. In general, lessons are opened by means of pictures showing more or less dramatic realities. Thus, thousands of textbook chapters and teaching sequences on climate change begin with pictures of flood- or drought-stricken regions, with polar bears floating on small ice floes in Arctic waters, or with dramatic pictures documenting glacier retreat in high mountains. The topic of soil degradation is introduced with drastic erosion damage or gleaming white areas of salinisation, or introductory images show emaciated people or migrants on the move to open up the topics of hunger, poverty and migration. The further course of the majority of these approaches, which seem to be firmly established in our teaching culture, focuses on the causes and dimensions of the respective problem before a possible solution is finally addressed and discussed with the students. In many cases, approaches and concepts of sustainable development are addressed in a topic-specific manner in this context and are also taken more intensively into consideration, so that all aspects are sufficiently taken into account.

It is worthwhile to reflect on this approach, which has been widely cultivated for years. It is especially important to reflect on the effect of this approach on the students. How is subject matter taught in this way, perceived from the perspective of 16- or 17-year-olds? Their perception of the subject area of global challenges introduced in this way is linked to their own life perspective and at the same time is strongly 'emotionalised'. Here is an example: the opening page of a textbook chapter entitled The Future of the Earth is dominated by two pictures. One shows a huge traffic intersection with several lanes, without any enlivening greenery in sight or any kind of settlement. The second picture directs the viewer's gaze over a space with dry cracks almost devoid of vegetation, two women carrying small water containers. The images convey hostile spaces. From the students' point of view, the first encounter is not primarily an analytical, sober consideration of a problem to be solved. Rather, in the sense of the highly emotionalised process of perception and understanding described by the American psychologist Daniel Kahnemann as "fast thinking" (cf. Kahnemann, 2011), they perceive the real scenes or future scenarios presented in the image as a determining factor in their own lives, which may not be factually wrong. The resulting reaction, which is also emotionally dominated, may vary in intensity from one individual to another. It ranges from hopelessness to resignation, encompasses worry, danger, fear and threat, and brings doomsday scenarios into the realm of the expected. Neither of these extremes provides an adequate basis from which the students can immediately engage with the global challenges presented in a solution-oriented manner, but instead sets discussions in motion along the lines of the fears triggered. This effect, which can be observed again and again in the reality of teaching and which is expressed in discussions with students, must surely be a reason to consider alternative approaches. The solution-focused approach to teaching outlined below could be seen as an option. 


\section{A solution-focused teaching approach}

The development of a solution-focused teaching approach in the context of the thematic field of SDGs or global challenges has to be seen also against the background of the debate about the educational value of the subject Geography in our time. This can be focused on the following four points:

- Analyse, discuss and evaluate natural and social phenomena and processes in a fundamentally integrative and systemic way;

- Analyse, discuss and evaluate spaces on all scales from the local to the regional to the global dimension in a question-oriented manner;

- Examine spaces on all scales in a problem-solving and action-oriented way, especially in the sense of the principle of sustainability; and

- Orient the temporal perspective towards the present and the future.

On the basis of these objectives, it becomes clear that a solution and future orientation based on the principle of sustainability is of particular importance, as has been acknowledged for the competence orientation of Education for Sustainable Development in recent years (outlined above).

While the problem-oriented teaching approach focuses on the problem, such as the worldwide water shortage, and deals exclusively with the various facets of the problem itself, the problem-solution-oriented approach goes one step further. Like the problemoriented approach, the problem-solving approach begins with the problem and deals with it in detail, but then moves on to ask about possible solutions and discusses these in detail and in a targeted manner. One advantage of this fact-based approach is that solutions discussed are highly attuned to a detailed analysis of the problem and can thus be perceived and evaluated as a concrete mechanism that is close to reality.

In contrast to these two approaches, the solution-focused approach focuses more on the engagement with and discussion of proposed solutions and approaches. Following this approach, the solution proposals already form the introduction to the lesson and take considerably more lesson time than the problem constellation. This is illustrated with an example of resource scarcity as a topic to be taught (Figure 5). If a lesson on the topic of resource scarcity begins with a discussion about a Fairphone, for example, or a lesson on emissions and climate change begins with a concept for intelligent street lighting, or a lesson on the world water crisis begins with the presentation of an environmental award to the developer of a new type of high-performance ceramic filter, then students are immediately intrigued and usually react with curiosity. This can lead to them wanting to participate in the development of such clever ideas. This positive reaction is usually followed by questions from the students themselves about the effectiveness of the idea presented, so that the next step in the lesson is to ask about the dimensions and quality of the problem to which the proposed solution is supposed to be an answer. In this context, the operator "to verify" must be given central importance. This is because at the core of the solution-focused teaching 
approach presented here is the question: How good is this solution-focused approach? Can the Fairphone solve the environmental and socio-economic problems of thousands of children mining for tantalum and coltan in the mines of East Africa? Is the technology of intelligent street lighting, as tested in Ludwigsburg, Germany, a serious contribution to overcoming energy problems? Or, does the ceramic filter solve the deficits of a clean drinking water supply that can be observed particularly in the Global South?

The example of the shortage of resources due to cell phone production is used in Figure 5 to illustrate this point.

Figure 5: Problem-solution-oriented vs. solution-focused teaching approach - an example of 'Resource scarcity due to cell phone production' (author developed)

\section{Problem-solution-oriented teaching approach}

\begin{tabular}{|c|c|c|c|c|}
\hline $\begin{array}{l}\text { Problem/global } \\
\text { challenge }\end{array}$ & $\begin{array}{l}\text { Which reasons } \\
\text { can be } \\
\text { identified? }\end{array}$ & $\begin{array}{l}\text { To which } \\
\text { dimensions can } \\
\text { the problem } \\
\text { grow? }\end{array}$ & $\begin{array}{l}\text { Which } \\
\text { consequences } \\
\text { are to be } \\
\text { named? }\end{array}$ & $\begin{array}{l}\text { What could a } \\
\text { solution look } \\
\text { like? }\end{array}$ \\
\hline $\begin{array}{l}\text { Dramatic picture } \\
\text { of child labour in } \\
\text { the coltan mines } \\
\text { of East Africa, } \\
\text { e.g. in the Congo }\end{array}$ & $\begin{array}{l}\text { Price pressure } \\
\text { requires } \\
\text { disregard of } \\
\text { social and } \\
\text { environment- } \\
\text { tal standards, } \\
\text { high demand, } \\
\text { permanent } \\
\text { innovation,... }\end{array}$ & $\begin{array}{l}\text { Depletion of } \\
\text { resources, } \\
\text { such as coltan, } \\
\text { massive } \\
\text { injustice and } \\
\text { environmental } \\
\text { degradation,... }\end{array}$ & $\begin{array}{l}\text { Price increase, } \\
\text { threat to raw } \\
\text { material supply, } \\
\text { economic } \\
\text { degression, ... }\end{array}$ & $\begin{array}{l}\text { Legal ban on } \\
\text { child labour } \\
\text { in mines, buy } \\
\text { fewer cell } \\
\text { phones, use cell } \\
\text { phones longer, } \\
\text {.... }\end{array}$ \\
\hline
\end{tabular}

\section{Solution-focused teaching approach}

\begin{tabular}{|c|c|c|c|c|}
\hline $\begin{array}{l}\text { Fascinating idea } \\
\text { or suggested } \\
\text { solution }\end{array}$ & $\begin{array}{l}\text { Curiosity / } \\
\text { fascination } \\
\text { How is that } \\
\text { possible? }\end{array}$ & $\begin{array}{l}\text { What is the } \\
\text { problem? }\end{array}$ & $\begin{array}{l}\text { How far does } \\
\text { the suggested } \\
\text { solution reach? } \\
\text { Is it transferable } \\
\text { to other regions } \\
\text { or contexts? }\end{array}$ & $\begin{array}{l}\text { How to solve } \\
\text { the remaining } \\
\text { problems? }\end{array}$ \\
\hline $\begin{array}{l}\text { Introducing a } \\
\text { Fairphone, } \\
\text { Note: This is to } \\
\text { contribute to the } \\
\text { solution of the } \\
\text { resource issue } \\
\text { and inequality. }\end{array}$ & $\begin{array}{l}\text { Curiosity, } \\
\text { demand, } \\
\text { interest } \\
\text { How does it } \\
\text { work? }\end{array}$ & $\begin{array}{l}\text { Depletion of } \\
\text { resources, } \\
\text { such as coltan, } \\
\text { massive } \\
\text { injustice and } \\
\text { environmental } \\
\text { degradation,... }\end{array}$ & $\begin{array}{l}\text { Expensive, } \\
\text { not affordable } \\
\text { by all, fewer } \\
\text { functions in } \\
\text { comparison, } \\
\text { repairable, can } \\
\text { be expanded, } \\
\text { meets } \\
\text { social and } \\
\text { environmental } \\
\text { standards }\end{array}$ & $\begin{array}{l}\text { Overcoming } \\
\text { technical } \\
\text { deficits, } \\
\text { checking more } \\
\text { favourable } \\
\text { pricing, if } \\
\text { necessary } \\
\text { statutory } \\
\text { regulation } \\
\text { of recycling } \\
\text { quota or waste } \\
\text { reduction }\end{array}$ \\
\hline
\end{tabular}


In contrast to the problem-solving approach to teaching, the students working with a solution-focused teaching approach enter a solution-focused mode of thinking from the very beginning. The reactions of resignation, worry or even fear familiar in other teaching approaches are largely absent. Experience shows that a solution-focused mode of thinking is largely maintained even when the dimensions and effects of global challenges are at the centre of the subsequent classroom activity. It is important to maintain this throughout the entire course of instruction, and ideally even to support the development of this way of thinking as a basic attitude among young people.

If this kind of solution-focused lesson opening leads to examining the effectiveness of a fascinating innovation, its possible transferability and global application, the next step is to deal with the dimensions, causes and effects of the global challenge from the perspective of the solution. This stimulates the desired creativity, future and solution-orientation, but also critical thinking, which are among the key competencies to be developed in the context of Education for Sustainable Development. The associated pedagogical-psychological effect is enormous, because the students perceive themselves in an open thinking space in which they can develop their own creativity and take on the challenges posed in a solution-oriented manner and, depending on the lesson design, also experience a sense of self-efficacy.

From an educational-psychological perspective, the strongest argument in favour of this approach is that, when appropriately designed, it does not encourage depressive moods or a sense of hopelessness. This is true even if an initial fascinating idea or the proposed solution can only partially or under extreme conditions overcome a global challenge. In such situations, it has been noticed that most students ask: How do we solve the remaining problem(s)?

The implementation of a solution-focused teaching approach is illustrated in the textbook Globale Herausforderungen. Die Zukunft, die wir wollen (Global Challenges - The future we want) (Hoffmann, 2018b). It is follows in large parts the factual logic of the traditional problem-solving approach. However, the decisive factor - the paradigm shift of this approach - is to place the solution ideas at the beginning and to deal with them primarily and critically, constructively for the longest part of the lesson, without downplaying or ignoring the global challenges, their scale or their potential danger. In contrast, widespread teaching practice devotes most of the class time to the problem and only discusses possible solutions at the end, to a limited extent and in a short period of time.

Proposed solutions are by no means limited to technical innovations or resourceand energy-saving processes, but can also be in the form of 'stories of change'. This approach is the basis of the teaching manual Teaching Sustainable Development Goals (Hoffmann \& Gorana, 2017). ${ }^{1}$ In this guide each of the 17 goals is presented with regard to the official formulation of the goals, the global conditions that need to be overcome, and possible didactic-methodical approaches. In addition, and this is the key characteristic of this teaching material, a real story is told about each of the 17 SDGs. This is designed with the culture-changing effect of narratives propagated by Harald Welzer (2014) in mind. Narratives are to be understood as collective stories and concepts with which 
each individual associates positive experiences. For example, narratives such as personal freedom, freedom of movement, opportunities for development, democracy or consumer orientation, and others, are the starting point of positive individual experiences, which in their sum contribute to social cohesion and can certainly be understood as cultureforming. Narratives not only reflect cultures, but can also change them. Thus, narratives can be used as an instrument for social change and therefore can also be misused. Following these considerations, the Teaching SDGs manual tells a 'story of change' for each of the 17 goals. Against the backdrop of the international ESD Expert Net working group and with the aim of learning from one another, four 'stories of change' were compiled from each of the countries involved in the project - India, Mexico, South Africa and Germany - while the story of ESD ExpertNet itself was told for SDG 17, which formulates the formation of global partnerships as a goal.

To illustrate these conceptual foundations, one of these stories is presented here:

\section{The curious case of Whali in Mangrol}

When Kunal and his friends visit their fishing nets, which they place off the coast of Gujarat, they can see, already from a distance, whether their nets have been destroyed or not. Coming closer, they see one of the most impressive species of the oceans: a whale shark. Kunal bows over the edge of his boat, cuts several metres of the net and releases Whali to the open sea. Neither his father nor his grandfather would have done this. They would have been delighted with such a huge catch. In 2004, a spiritual Hindu leader, Morari Bapu, addressed the village community of Mangrol, a small settlement on the coast of Gujarat in India, urging them to protect the whale sharks - the largest fish in the sea. Whale sharks reach lengths of 40 feet or more. Morari Bapu called it Whali, which means "dear one". He used the metaphor of a daughter coming to her maternal home. In the Indian custom a daughter, where possible, delivers her first child in the place of her own childhood. And, of course, nobody would consider harming her. The Gujarat coastal region is a breeding area for the whale sharks. Whale sharks were being killed by the fishermen for liver oil and meat after getting caught in the nets. The population of the whale sharks on the Gujarat coast dwindled drastically from 1995 to 2000. In 2001, whale sharks were included in IUCN Endangered Species List. The same year, fish species were brought under Schedule I of the Wildlife Protection Act of India. Since then, poaching whale sharks has been made punishable under the Wildlife Protection Act. Seeing no abatement in the killings, the Wildlife Trust of India launched a massive public campaign - 'Save the whale shark'. This campaign included the local community, fishermen and Morari Bapu. Tata Chemicals stepped in to compensate fisher folks who had to cut their nets to let the big fish get away into deep waters. The compensation benefitted both people and the whale sharks. The campaign led to the protection of 585 whale sharks and became one of the biggest whole community efforts to protect the largest species of fish. Indeed, Mangrol became the world's largest site for the protection of whale sharks! The efforts of the village community, fisher-folks, state forest department, international NGOs, and corporates made it possible to protect the whale shark. (Hoffmann \& Gorana, 2017, pp. 63-64) 
With such narratives of change, not only is the specific objective of SDG 14 "to conserve and sustainably use the oceans, seas and marine resources for sustainable development" made clear, but learners also learn, through further narratives, that there have been a multitude of successful approaches, projects, measures, initiatives and deeds that have contributed to the realisation of all SDGs.

Departure from the commonly practised teaching approaches involving discussions in the subjunctive, in favour of teaching in the indicative has an effect. However, this approach must be wary of becoming a form of indoctrination, for example, expecting students to adopt a particular solution such as solar power or electric vehicles uncritically. With all the enthusiasm for ideas or stories, it is essential to maintain a critically analytical perspective. This is the only way to ensure that students gradually realise that active participation in shaping a sustainable society is based on the following three steps:

- The cleanly conducted, critically reflective analysis of the current situation;

- A realistic, clearly formulated goal oriented to the principle of sustainability, and

- The personal determination to act consistently in favour of the formulated objective.

\section{Conclusion}

It is vital to establish the SDGs or their reflection of reality, which can be described as global challenges, as an integral component of Geography and related lessons. However, with regard to concrete implementation in the classroom, there are long-established problem (or problem-solving) oriented approaches, which have been contrasted here with a solutionfocused approach as an innovative proposal. The application of this solution-focused approach must not be based on naive good faith, as its implementation is tantamount to a tightrope walk. On the one hand, this approach promotes anticipatory and critical thinking, is solution and future-oriented, stimulates creativity, motivates and activates the students and can thus rightly be seen as a significant contribution to action orientation as a desired outcome of Education for Sustainable Development. On the other hand, however, such a solution-focused teaching approach could also lead to blind faith in technology on the part of the students, to the trivialisation of the problem dimensions and their urgency and, as a result, to students indulging in carelessness and deliberately chosen inactivity. Educators and teacher educators need to see and evaluate these advantages and potential disadvantages for themselves. However, in the final analysis, when the pedagogicalpsychological effects and the associated containment of future fears generated by the alternative approaches are included in the overall evaluation, the pendulum swings (for me) in favour of a solution-focused teaching approach.

Against this background, I propose that this teaching approach be actively tested. It automatically introduces more "Eureka!" moments and can be seen as a "provocation of the future" (cf. Land, 2018) into our teaching and into our societies, which can only be to our 
benefit in view of the global challenges to be met in our "full world" (cf. Weizsäcker, et al., 2017). Therefore, a solution-focused teaching approach is at least worth an attempt!

\section{Notes on Contributor}

Hoffmann, Thomas

Thomas Hoffmann is the Head of the Geography Department at the Teacher Training Centre in Karlsruhe, Germany. He is an Honorary Professor at Leuphana University, Lüneburg and a lecturer in Geography Didactics at Karlsruhe Institute for Technology (KIT). He is also a founding member of ESD Expert Net, an intercultural think tank on ESD.

\section{References}

Göpel, M. (2020). Unsere Welt Neu Denken. Eine Einladung. Berlin: Ullstein.

Hoffmann, T. (2018a). Gerüstet für die Zukunft: Aufgaben des Geographieunterrichts. Praxis Geographie, 48(1), 4-9.

Hoffmann, T. (2018b). Globale Herausforderungen. Die Zukunft, die wir wollen. Stuttgart: Klett.

Hoffmann, T. \& Gorana, R. (2017). Teaching Sustainable Development Goals. Bonn: Engagement Global.

IPBES (Intergovernmental Platform on Biodiversity and Ecosystem Services ).(2021). Nature's Dangerous Decline 'Unprecedented'; Species Extinction Rates 'Accelerating. Retrieved from https://ipbes.net/news/Media-Release-Global-Assessment

Kahnemann, D. (2011). Schnelles Denken, Langsames Denken. München: Siedler. Land, K-H. (2018). Erde 5.0. Die Zukunft provozieren. Köln: Future Vision Press. Martens, J. \& Obenland, W. (2017). Die Agenda 2030. Globale Zukunftsziele für nachhaltige Entwicklung. Bonn/Osnabrück: Global Policy Forum und Terre des hommes.

Osterhammel, J. (2016). Die Verwandlung der Welt. München: Beck.

Raworth, K. (2016). Donut Ökonomie. München: Hanser.

Steffen, W., Broadgate, W., Deutsch, L., Gaffney, O., \& Ludwiget, C. (2015). The trajectory of the Anthropocene: The great acceleration. Anthropocene Review, 81-98.

Welzer, H. (2014). Selbst Denken. Frankfurt/Main: Fischer.

Welzer, H. (2019). Alles Könnte Anders Sein. Eine Gesellschaftsutopie für freie Menschen. Frankfurt/Main: Fischer.

UNESCO. (2017). Education for Sustainable Development. Learning Objectives. Paris: UNESCO.

United Nations. (2015). Transforming our world: The 2030 Agenda for Sustainable Development. New York: United Nations. Retrieved from https://www.un.org/en/ development/desa/population/migration/generalassembly/docs/globalcompact/A_ RES_70_1_E.pdf 
Weizsäcker, E. \& Wijkman, A. (2017). Wir sind dran. Was wir ändern müssen, wenn wir bleiben wollen. Eine neue Aufklärung für eine volle Welt. Gütersloh: Bertelsmann.

WBGU (Wissenschaftlicher Beirat der Bundesregierung Globale Umweltveränderungen). (2021). Rethinking Land in the Anthropocene: From separation to integration. Berlin: WBGU.

\section{Endnotes}

1 Teaching Sustainable Development Goals (Hoffmann \& Gorana, 2017) https://esd-expert.net/teaching-and-learning-materials.html 